University of Nebraska - Lincoln

DigitalCommons@University of Nebraska - Lincoln

USDA National Wildlife Research Center - Staff Publications
U.S. Department of Agriculture: Animal and Plant Health Inspection Service

2020

\title{
Invasive Species Control and Resolution of Wildlife Damage Conflicts: A Framework for Chemical and Genetically Based Management Methods
}

\author{
Larry Clark \\ APHIS, clark@metis4u.net \\ John Eisemann \\ USDA-APHIS-Wildlife Services, John.D.Eisemann@aphis.usda.gov \\ John Godwin \\ North Carolina State University, godwin@ncsu.edu \\ Katherine Horak
}

U.S. Department of Agriculture, katherine.e.horak@aphis.usda.gov

KeUPMW OHis and additional works at: https://digitalcommons.unl.edu/icwdm_usdanwrc

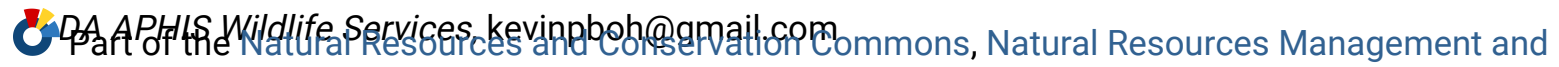

Policy Commons, Other Environmental Sciences Commons, Other Veterinary Medicine Commons,

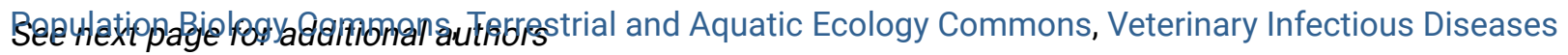

Commons, Veterinary Microbiology and Immunobiology Commons, Veterinary Preventive Medicine,

Epidemiology, and Public Health Commons, and the Zoology Commons

Clark, Larry; Eisemann, John; Godwin, John; Horak, Katherine; Oh, Kevin; O'Hare, Jeanette R.; Piaggio, Antoinette J.; Pepin, Kim M.; and Ruell, Emily W., "Invasive Species Control and Resolution of Wildlife Damage Conflicts: A Framework for Chemical and Genetically Based Management Methods" (2020). USDA National Wildlife Research Center - Staff Publications. 2390.

https://digitalcommons.unl.edu/icwdm_usdanwrc/2390

This Article is brought to you for free and open access by the U.S. Department of Agriculture: Animal and Plant Health Inspection Service at DigitalCommons@University of Nebraska - Lincoln. It has been accepted for inclusion in USDA National Wildlife Research Center - Staff Publications by an authorized administrator of DigitalCommons@University of Nebraska - Lincoln. 


\section{Authors}

Larry Clark, John Eisemann, John Godwin, Katherine Horak, Kevin Oh, Jeanette R. O'Hare, Antoinette J. Piaggio, Kim M. Pepin, and Emily W. Ruell 


\title{
Invasive Species Control and Resolution of Wildlife Damage Conflicts: A Framework for Chemical and Genetically Based Management Methods
}

\author{
Larry Clark, John Eisemann, John Godwin, Katherine E. Horak, Kevin Oh, \\ Jeanette O’Hare, Antoinette Piaggio, Kimberley Pepin, and Emily Ruell
}

\begin{abstract}
Vertebrate wildlife damage management relates to developing and employing methods to mitigate against damage caused by wildlife in the areas of food production, property damage, and animal or human health and safety. Of the many management tools available, chemical methods (e.g., toxicants) draw the most attention owing to issues related to environmental burden, species specificity, and humaneness. Research and development focusing on RNA interference and gene drives may be able to address the technical aspects of performance goals. However, there remain many questions about regulation, environmental risk, and societal acceptance for these emerging biological technologies. Here we focus on the development and use of these biological technologies for use in vertebrate pest management and conservation (e.g., management of wildlife diseases). We then discuss the regulatory framework and challenges these technologies present and conclude with a discussion on factors to consider for enabling these technologies for pest management and conservation applications under a commercially applied framework.
\end{abstract}

Keywords Gene drive $\cdot$ Gene silencing $\cdot$ RNAi $\cdot$ Wildlife $\cdot$ Regulation $\cdot$ Product development $\cdot$ Pest control

\footnotetext{
L. Clark · J. Eisemann $(\triangle) \cdot$ K. E. Horak $\cdot$ K. Oh · J. O’Hare · A. Piaggio $\cdot$ K. Pepin · E. Ruell National Wildlife Research Center, Wildlife Services, Animal and Plant Health Inspection Service, United States Department of Agriculture, Fort Collins, CO, USA

e-mail: john.d.eisemann@usda.gov

J. Godwin

Department of Biological Sciences, North Carolina State University, Raleigh, NC, USA
}

A. Chaurasia et al. (eds.), GMOs, Topics in Biodiversity and Conservation 19, https://doi.org/10.1007/978-3-030-53183-6_9 


\section{Introduction}

The field of vertebrate wildlife damage management relates to developing and employing methods to mitigate damage caused by wildlife in the areas of food production, property damage, and animal or human health and safety (Conover 2001). The methods used to resolve such conflicts include the use of physical devices (e.g., traps, sonic or visual scaring methods), chemical methods (e.g., reproductive inhibitors, repellents, toxicants), direct lethal control (e.g., culling), and alterations to the landscape (e.g., habitat manipulation). Unlike other areas of wildlife management that involve natural resource protection for conservation or sustainable consumptive and nonconsumptive recreational use, wildlife damage management seeks to alter animal behavior or circumstances to prevent damage to human activity or interests that may be caused by wildlife and hence involve more direct and interactive approaches to management.

For the most part, the technologies and methods used by wildlife damage managers have long histories (Reidinger Jr and Miller 2013). Among the many management tools, chemical toxicants have proven to be both effective and controversial (Eason et al. 2010). For the most part, criticism has focused on five areas: effectiveness, need and/or alternatives, humaneness, nontarget effects, and environmental burden. Thus, imperative for managers in the development of new technologies is to consider developing methods that provide for sustainable agricultural production and natural resource stewardship within a social license framework.

If the use of vertebrate pesticides is required, then it is desirable for them to be species-specific, thus eliminating direct nontarget risks. The pesticide should also reduce environmental and ecological burden. That is to say, once the target effect is achieved, diffusion into the environment and amplification through the food chain should not occur, thus eliminating indirect nontarget effects. The mode of action for the pesticide should reduce animal awareness to pain and have a short time to death, both traits that contribute to current standards for humane death (Underwood et al. 2013). As the science evolves and the options for mode of action and nature of the pesticide broaden, there should be regulatory clarity from authorizing agencies and guidance to users in the form of approved labeling and licensing of products. Because the research, development, and regulatory processes are complex and not necessarily familiar to wildlife damage managers, it is vital that communication among the developing partners is well founded and follows an orderly process so that formulation, effectiveness testing, technology transfer, production, delivery, and scalability result in a cost-effective product that is easily applied on a landscape scale. Finally, and perhaps most importantly, it is imperative that a communication and engagement plan is developed for users and the community. It does little good to develop an expensive tool only to have it fail because of unanticipated or unaddressed concerns within the human social and political framework.

Traditional strategies to control pest species include biological (use of predators, crop rotation), mechanical (physical removal), and chemical (toxicants, repellents). Biological and mechanical methods are often chosen to limit the use of chemicals 
as a means to reduce impacts to the environment and nontarget species (Damalas and Eleftherohorinos 2011; Kogan 1998; Witmer 2007). Yet chemical methods may be favored because pest population control often occurs more quickly and with less monetary investment than when other techniques are used. More recently, research has focused on development of biological pesticides that combine target specificity, humaneness, and low environmental burden with the response and cost efficiencies of traditional chemical applications, such as gene drive technology and RNA interference. These technologies hold the promise to address the objectives identified above and perhaps decrease the reliance on use of chemical pesticides.

Here we focus on the development and use of two technologies that hold promise as tools for vertebrate wildlife management and conservation: gene silencing through RNA interference and gene drives.

\section{Gene Silencing}

Interest in RNA interference (RNAi) as a tool for basic research and for the treatment of diseases started with its discovery in the 1990s. Since then, the utility of RNAi as a means to control pest species has become increasingly popular. Successes in the development of RNAi toxicants to control insects and novel methods using plants as a means to deliver RNAi to feeding insects have expanded initial expectations of the applications of this technology. In 2017, the US Environmental Protection Agency (EPA) registered the first RNAi-based insecticide for the control of Western corn rootworm (Diabrotica virgifera virgifera). This EPA registration ushers in a new era in toxicant development with the ability to design toxicants that are species-specific alleviating concerns of risks to nontarget species, and following the promise shown for insect control, there is increasing interest for use of this technology for applications in vertebrate pest management.

RNA interference (RNAi) is a fundamental cellular process that controls what genes are turned on and off by determining what proteins are synthesized from the messenger RNA (mRNA) messages in the cytoplasm. RNAi shows promise as a class of species-specific toxicants because RNAi molecules, by design, bind specifically to a single mRNA triggering its destruction. The instructions for protein synthesis travel from DNA in the nucleus to the cytoplasm by messenger RNA (mRNA) (Crick 1970). These single-stranded mRNA molecules are composed of unique sequences of nucleotides that code for specific proteins.

The first indication that translation from mRNA to protein may be influenced by exogenous RNA sequences came when Jorgensen (1998) attempted to increase the purple pigment in petunia flowers by injecting extra copies of the pigment gene into the plant. The result of these injections was not flowers that were more purple, but surprisingly yielded either two-toned or totally white flowers (Fire et al. 1998; Jorgensen et al. 1998; Napoli et al. 1990). Jorgensen termed this phenomenon "cosuppression." This was the first experimental demonstration of the process now 
called RNA interference for which Andrew Z. Fire and Craig C. Mello were awarded a Nobel Prize in 2006.

RNAi is dependent on the inherent protective pathway within cells that degrades mRNA. Double-stranded RNA (dsRNA) binds to a protein called Dicer that cleaves the dsRNA into smaller fragments that are then integrated into the RNA-induced silencing complex, RISC (Liu et al. 2004; Tang 2005; Zhang et al. 2004). The RISC complex then separates the short dsRNA fragments into single-stranded segments, one of which is shuttled to and binds the matching mRNA sequencing that was transcribed from DNA. The complex formed by the RISC (with fragment of the initial dsRNA) and the mRNA then cleaves and degrades the mRNA guided by properties of the fragment of the initial dsRNA (Khvorova et al. 2003; Schwarz et al. 2003). The gene for which the mRNA is coded is, therefore, not synthesized, and the gene is "silenced." Since its discovery, this sequence-specific gene silencing has shown great promise as both a research tool and in the treatment of diseases (Lares et al. 2010). More recently, interest in using RNAi as a means to control pest species has become increasingly popular; however, to date, this interest has been focused on insect pests (Baum and Roberts 2014; Burand and Hunter 2013; Mamta and Rajam 2017; Niu et al. 2018; Zotti et al. 2018).

\section{Gene Silencing: Pest Control and Risk}

The success of RNAi as a "chemical" means to control pest species depends on multiple factors. Though the RNAi pathways are inherently present in cells, introduction of exogenous RNAi is still recognized as nonself and therefore can elicit an immune response and subsequent release of inflammatory cytokines (Alexopoulou et al. 2001; Heil et al. 2004). Responses such as these are called off-target effects as they are not related to the desired physiological response from the RNAi-induced gene silencing. Significant effort is made during the design of RNAi molecules to reduce off-target effects and minimize immune response (Schwarz et al. 2003). Offtarget effects are a concern in nontarget species as they can occur even if the target sequence of the RNAi is not present in the nontarget animal. Nontarget species will not be affected by the directed silencing of specific genes, but the RNAi must not elicit an immune response in nontarget species. If successful, one of the benefits of RNAi over traditional chemical toxicants is its species specificity. Comparisons between gene sequences in target and nontarget species are done to determine regions of the genes that are the most different. RNAi molecules are then designed to those regions. These sequence differences result in a mismatch between the RNA incorporated in the RISC complex and the mRNA in the cytoplasm, blocking degradation of the mRNA (Amarzguioui et al. 2003). It is possible to design RNAi molecules that differ from target mRNA by a single nucleotide and therefore do not bind; purine/purine mismatches offer the highest level of discrimination (Schwarz et al. 2006). Nucleotide mismatches in different regions of the RNAi also affect specificity, with the last two nucleotides of the same types of RNAi molecules not 
contributing to binding to the mRNA (Elbashir et al. 2001), so mismatches in those regions do not affect binding and subsequent mRNA degradation. The requirement of exact matching of RNAi and target mRNA sequences places a burden on the development of RNAi-based chemical toxicants, as genes of wildlife species are often not sequenced. In addition, ensuring the target sequence in conserved diverse animal populations that are geographically separated needs to be done before sequences are registered for use as toxicants.

Using RNAi as a means to control pest populations is contingent on delivery of the nucleotide sequence to both the target species and the desired location in the organism. Toxicant baits containing RNAi face the same requirements as traditional chemical toxicant baits of attractiveness to target species and stability in harsh environmental conditions. This is a challenge as RNAi is, by its nature, unstable. Modifications to the RNAi sequences, such as the addition of 2'-O-methylpurines or 2-fluoropyrimidines, have been shown to increase stability without decreasing effectiveness (Czauderna et al. 2003). Once the pest species consumes the RNAi bait, getting the RNAi to the target tissue in appropriate concentration becomes the next hurdle. RNAi baits will be formulated for oral delivery meaning the RNAi will have to survive the extreme conditions of the gastrointestinal tract before absorption into the systemic circulation. Lipid nanoparticle carriers have shown promise in protecting the RNAi from degradation at low digestive pH (Ball et al. 2018). Once in systemic circulation, the RNAi must get to the target location. This can be achieved through the addition of cell-type-specific ligands, antibodies, or receptors on the carrier molecule. Uptake of the RNAi by target cells can be facilitated by the use of cell-penetrating peptides, nanoparticles, and polymer-based delivery systems (Ahmadzada et al. 2018; Avila et al. 2016; Singh et al. 2018a, b). Once inside the cell, the RNAi will then silence the target gene by directed destruction of the mRNA.

There are numerous obstacles for delivery of an RNAi toxicant for use in vertebrate pests, from the development of the oral bait to shuttling the RNAi to the target tissue. However, research from human drug development and successes in the fields of insect control lay the foundation for vertebrate RNAi toxicant development and wildlife disease treatments in the field.

\section{Gene Drives}

Pest control technologies using RNAi have the potential to come to use sooner and under a clear regulatory framework (see below). Such technologies will also most likely be applied similar to traditional chemical pesticides. However, gene drive technologies hold the promise of being self-sustaining once released, thus eliminating the need for constant reapplication. It is this feature which is both appealing from an economic logistical perspective and warrants caution from an environmental risk perspective.

It is not difficult to find popular news stories about the promise and potential catastrophe that could be realized through the application of clustered regularly 
interspaced short palindromic repeats (CRISPR) and CRISPR-associated proteins for genome editing and DNA. CRISPR-Cas systems have been identified from bacteria and archaea and provide immunity to ward off bacteriophages (Barrangou 2015). When harnessed for genome editing, the system has been shown to provide targeted, sequence-specific cleavage of double-stranded DNA (Mali et al. 2013; Jiang et al. 2013). This is accomplished through the precise delivery of endonuclease enzymes by synthetic single-guide RNA (sgRNA) that are engineered to bind only to specific target sequences within the genome. These DNA cleavages will then be repaired by the targeted genome through either homology-directed repair (HDR) or nonhomologous end joining (NHEJ). HDR repairs with a homologue piece of DNA, whereas NHEJ directly ligates the cleaved pieces of DNA and thus can lead to a loss of nucleotides and other potential errors. With an engineered template, the HDR process will repair the nicked DNA with a synthetic portion of DNA on both DNA strands (Mali et al. 2013; Alphey 2014; Doudna and Charpentier 2014). Thus, through the CRISPR-Cas system, double-stranded DNA can be cleaved at a targeted site and repaired with a synthetic piece of DNA, which can then be copied in the organism through regular genomic copying. Application of this technology has been coined "synthetic biology," and its utility has been realized in the pharmaceutical and agricultural production already (Carlson 2010; Church and Regis 2012; Doudna and Charpentier 2014; Gantz et al. 2015; Lander 2016; Hussain et al. 2018).

Because gene drive applications would not require constant application in the sense of traditional chemical pesticides or even RNAi, there is inherent appeal to managers that the management tool will be self-sustaining, whether for pest management or for control of disease susceptibility for wildlife conservation purposes, e.g., avian malaria for protection of birds or plague resistance for protection of endangered species.

\section{Gene Drives: Uses for Disease Mitigation}

Disease control is typically accomplished by reductions in host or vector abundance, reduction of contact between hosts and pathogens, or increase in the refractoriness or resistance of hosts or vectors to infections (Sokolow et al. 2019). Traditional techniques include host culling, pesticides for vector control, physical barriers between hosts and vectors, vaccination to reduce transmission, or treatment to reduce severity and transmission. All of these interventions can be expensive and time-consuming and have variable levels of effectiveness depending on ecological conditions. Pesticide application can present health risks to humans and domestic animals through contamination of soil or water supplies. Genetic modification (GM) techniques can be developed to target genes that could affect any of these processes and have the potential to be cheaper and more effective and have lower host or environmental burden. For example, GM approaches can be designed to target specific isolates or strains of a bacterium, which is advantageous over antibiotics because the specificity allows "good" bacteria to be unaffected (Barrangou and 
Doudna 2016). Strain-specific editing of bacterial populations is particularly useful in food biotechnology where CRISPR systems have been used to vaccinate industrial bacterial cultures against viruses or to engineer antibiotic resistance uptake or probiotic cultures (Selle and Barrangou 2015a, b). Similarly, it was recently shown that a CRISPR-Cas13a system could be used to engineer potato plants to be resistant to potato virus $\mathrm{Y}$ while having no effect on related viruses such as potato virus A (Zhan et al. 2019). The ability to efficiently protect crops or livestock against specific agricultural diseases could dramatically improve food security while reducing the ecological footprint of agriculture (Herman et al. 2019; Van Eenennaam and Young 2014).

One of the most active areas of disease control research has been to create gene drives that repress vector populations or make them refractory to pathogens that cause human diseases such as dengue or malaria (Ferguson 2018; Shaw and Catteruccia 2019). For example, Anopheles stephensi, a vector of the malaria parasite Plasmodium spp., has been successfully engineered to have much reduced vector competence relative to wild-type vector individuals (Gantz et al. 2015; Ito et al. 2002). More recently, it has been demonstrated that a CRISPR-Cas 9 system for delivery of a female sterility trait could spread to $100 \%$ prevalence in $7-11$ generations in caged Anopheles mosquitoes (Kyrou et al. 2018). Similar results have been obtained using other gene targets (Hammond et al. 2016), suggesting that there is ample opportunity to choose a target that will be successful in a particular ecological context (Champer et al. 2016). While not yet realized, the ability to protect livestock against specific diseases efficiently using CRISPR technology is on the horizon (Conklin 2019; Lamas-Toranzo et al. 2017).

\section{Gene Drives: Uses for Conservation}

Invasive mammalian predators represent a major threat to biodiversity worldwide. Doherty et al. (2016) estimated mammalian predators are responsible for the extinction of at least 142 vertebrate species since AD 1500 (58\% of the total including 87 bird, 45 mammal, and 10 reptile species) and threaten another 596 species. The key invasive vertebrate predator threats involve species from 13 mammalian families including rodents, felids, canids, and mustelids with seven species/groups in particular accounting for the bulk of the documented impacts on birds, mammals, and reptiles: cats, rodents, dogs, pigs, small Indian mongoose, red fox, and stoats. Of these, cats and rodents including three species of rats (Rattus spp.) and house mice (Mus musculus) have proven particularly damaging with island faunas being especially hard hit for several reasons. First, islands harbor a disproportionate share of biodiversity. Despite representing approximately 5\% of the Earth's land area, islands are home to $20 \%$ of described vertebrate species and approximately $40 \%$ of threatened and endangered species (Tershy et al. 2015; Spatz et al. 2017). Second, the populations of island endemic species are often much smaller and are therefore typically more vulnerable. Lastly, these island species have often evolved with few 
or no predators and consequently lack adaptive antipredator defenses (Adler and Levins 1994; Cuthbert et al. 2016).

Because islands are hot spots for both biodiversity and threatened and endangered species, managing threats in island ecosystems has also been a central focus for both conservationists and managers. In addition, for logistical reasons, islands represent isolated contained systems of limited geographic scale which will be critical for effective early phase testing and evaluation.

A major focus of efforts on islands has been eradication of invasive mammalian predators, and the outcomes have been tremendously positive (Cuthbert et al. 2011; Jones et al. 2016). Despite the significant conservation benefits realized through traditional eradication approaches, primarily aerial broadcast of rodenticides when targeting rats and mice, these methods have both significant drawbacks and some fundamental limitations (Campbell et al. 2015, 2019). The drawbacks include high fixed costs for operations (often in the millions of US dollars), nontarget species exposure to toxicants, and animal welfare concerns for both target and nontarget species (Mackay et al. 2007; Holmes et al. 2015). Failures and other rationales can often lead to significant social and political opposition. Lastly and critically, applying toxicant-based methods is extremely challenging on islands with human inhabitants, which represent the majority of islands where invasive mammals threaten biodiversity. Indeed, Campbell et al. (2019) estimate that fewer than $15 \%$ of islands worldwide where invasive rodents threaten critically threatened or endangered species are amenable to rodenticide-based eradication approaches. New approaches are clearly needed.

Genetic methods of pest control potentially offer a useful alternative to these established approaches. Although engineered gene drives harnessing either natural or synthetic drive mechanisms are still in the development phase, population modeling supports their potential effectiveness in reducing invasive mammal populations (Backus and Gross 2016; Prowse et al. 2017, 2019; Sudweeks et al. 2019). As detailed above, harnessing natural or synthetic selfish genetic elements in the form of gene drives could provide options not burdened by many of the drawbacks of rodenticide-based approaches. Specifically, genetic approaches could provide flexibility in financial models relative to the high fixed costs of rodenticide-based eradications, where operations typically must be conducted within short time windows. Genetic approaches should also be species-specific, eliminating at least direct effects on nontarget organisms. A gene drive approach would likely affect target pest populations through either biasing offspring sex ratios or inducing infertility in drive carriers, thereby leading to population reduction through natural attrition. This could alleviate animal welfare concerns that arise from the mechanism of action of toxicants currently. The species specificity of genetic approaches could facilitate use on inhabited islands due to the reduced threat to humans, pets, and livestock. However, use on inhabited islands could raise other concerns, including increased potential for movement of gene drive carriers from the targeted island and introduction of resistant individuals onto an island from nontarget populations. These are also new, unfamiliar, and as yet untested and unproven technologies, so a great deal 
of effort will need to be dedicated to engaging stakeholders and relevant publics in order to decide if, when, and how these approaches should be employed.

If a gene drive approach is employed for biodiversity conservation on islands, how is such an effort likely to proceed? While rats and cats represent more significant overall threats to biodiversity and have been discussed as potential target organisms for gene drive approaches (Moro et al. 2018), efforts to date have been focused on establishing feasibility in the house mouse. The feasibility of synthetic gene drive approaches has thus far only been demonstrated in insects and yeast (Gantz and Bier 2015; Gantz et al. 2015; Hammond et al. 2016; DiCarlo et al. 2015). The house mouse is the preeminent, most manipulable, and intensively studied mammalian genetic model organism with a rich knowledge base to support efforts to affect sex determination and fertility in this species (Campbell et al. 2019). No functional synthetic gene drive has yet been described for a vertebrate, and a recent report suggests generating one could prove challenging (Grunwald et al. 2019). Therefore, focusing on the most genetically tractable mammal is likely the best approach as well as advancing the general knowledge base necessary to advance efforts in other mammalian pest species should efforts in mice prove successful.

A number of factors including invasive species threaten terrestrial vertebrates worldwide (Allan et al. 2019). The foregoing discussion focused on use of genetic technologies on islands, which are favorable due to physical containment provided by geographic isolation. There is discussion of employing these technologies in a continental context and a recently launched effort to explore the potential of genetic approaches for controlling cats in Australia. Feral cats and red foxes represent the major current threat to Australia's terrestrial mammal fauna (Woinarski et al. 2015), and existing control strategies are not equal to this challenge. This has prompted consideration of gene drive approaches for control of feral cats (Moro et al. 2018; Kinnear 2018). Key knowledge gaps remain, and advances in understanding the potential of gene drive approaches for cats and other species will likely depend on progress in implementing these approaches in rodents first.

\section{Gene Drives: Risk}

There are several types of risk that must be considered in evaluating the potential utility of different pest control methods, such as ecological, evolutionary, economic, and ethical (Gould 2008). All methods of pest control share some risks in common (Herman et al. 2019). For example, reduction of pest populations can have ecological consequences in terms of ecosystem maintenance or community ecology (Gould 2008). Likewise, pesticide or repellant application or GM organisms can have economic risks due to evolution of resistance by the pest or ecological risks through negative impacts on nontarget species. Any pest control method can pose ethical risks through negative effects on human health or belief systems. All types of risks should be thoroughly evaluated before a new technology can be applied. 
For innovative pest control approaches, the first type of risk assessment pursuits typically are: Will the method work to reduce pest populations? How can we make it work most efficiently? How will it affect nontarget species or the ecosystem? Research to answer these questions then ensues. However, for GM organisms, there is an additional layer of complexity: what research directions are safe and ethical (Collins 2018; Courtier-Orgogozo et al. 2017)? The concept of GMOs, even for low-risk improvements to crop production, is not supported broadly in the human population (Linnhoff et al. 2017). It is important that differences in belief systems are thoroughly evaluated while defining research and technology directions for GM organisms (Shinwari et al. 2017). Questions of safety and ethics also have been hotly debated in related fields such as studying gain-of-function mutations for potentially pandemic viruses (National Research Council 2015; Lipsitch 2018). The rationale is that, without better safeguards in place, the risk of releasing a synthetically engineered strain that could overcome natural barriers in the fitness landscape and cause widespread devastation is much greater than the potential benefits that could be gained by understanding this strain's pathology and epidemiological dynamics. Similar concerns have arisen for GM pest control approaches, especially those with gene drive delivery (Abbasi 2016), because with super-Mendelian inheritance, these GM methods present a high risk of uncontrolled spread of genes (Akbari et al. 2015; Backus and Gross 2016; Dhole et al. 2018; Esvelt et al. 2014) that could have devastating consequences on nontarget populations. Thus, the perceived ecological risk of GM methods is so high that stringent containment conditions must be used even to study these methods in the laboratory (Benedict et al. 2018), and effects of these methods must be very well understood before they can proceed to contained field trials. This poses a severe but necessary limitation on the rate at which the technology should advance (Abbasi 2016).

Most of the literature applicable to wildlife focuses on the use of CRISPR-Cas systems to produce a "gene drive" or to push a trait introduced into a wildlife population to fixation or near fixation by avoiding Mendelian inheritance through inheritance by all offspring (Champer et al. 2016). This approach has been applied to some mosquito species that carry malaria that infects humans or Hawaiian birds and is being tested in laboratory and field experiments (Alphey 2014; Gantz et al. 2015; Hammond et al. 2016; Kyrou et al. 2018). In wildlife management, the application of this approach would need to be demonstrated in vertebrate species. This is a large technological leap from cells, insects, and even plants. However, the work of investigating the feasibility of CRISPR-Cas-mediated gene drives has begun in house mice (Piaggio et al. 2017; Grunwald et al. 2019) and thus holds promise for the control of invasive species and agricultural pests, which has been a promise of genetic engineering for over a decade (Burt 2003; Gould 2008).

Given the potential for synthetic gene drives to propagate rapidly within populations, the development of safeguards to spatially and temporally limit spread to nontarget organisms is a key technological challenge (Noble et al. 2018). Unlike most chemical-based management methods, RNA-guided gene drives are vertically transmitted, and thus, species-specificity is largely ensured by normal assortative mating among conspecifics. However, in many cases, the potential ecological 
impacts of uncontrolled spread into wildlife populations outside of the treatment area may present an unacceptable risk (Gould 2008).

A second major risk factor that is currently poorly understood is potential evolution of a gene drive system. History has shown over and over that strong selection can repeatedly and predictably produce resistance in pest species - antimicrobial resistance is a primary example. For traits that strongly influence fitness, mutations that occur during propagation of a deleterious gene can rapidly predominate, especially if they confer a fitness advantage. This has recently been observed in laboratory experiments with fruit flies (Drosophila melanogaster) to examine the efficiency of a CRISPR-Cas9 homing element for driving inheritance of a "Killer-Y chromosome" that results in all male offspring (KaramiNejadRanjbar et al. 2018). Here, gene-drive-resistant mutations readily arose in the mothers by in-frame indel mutations in the recognition site of the guide RNA, and these drive-resistant alleles strongly impacted efficiency of the drive system (KaramiNejadRanjbar et al. 2018), posing a potential economic risk for use in the wild. However, evolution of resistance could also pose ecological risks, and these mechanisms remain largely unexplored. For example, the mechanism by which a drive evolves could reduce target population specificity or even improve pest reproductive performance, thus increasing the risk to nontargets or other ecosystem impacts. Exploring the evolutionary landscape of candidate gene drive mechanisms using experimental evolution and loss-of-function mutational analyses in high containment settings are critical risk assessment steps to take. Importantly, these experiments need to occur using the specific target species and gene drive mechanisms of interest because specific evolutionary mechanisms can differ across systems.

In addition to experiments, risk assessment based on expert opinion (Beech et al. 2009) can help to prioritize risk factors to be investigated in more detail, thus improving efficiency of risk assessment. Simulation models are another efficient and safe approach to risk assessment. Simulation models can help guide the design of experiments efficiently (Restif et al. 2012) and improve our understanding of how different ecological and evolutionary processes interact to determine risk to nontarget individuals (Edgington and Alphey 2018). Models can be especially useful in high-dimensional systems where it is infeasible to test all potential factors empirically. While models are not a substitute for experimental data, they can predict which characteristics of a GM system might be safest and most efficient in a given ecological context (Dhole et al. 2018; Gemmell et al. 2013), improving efficiency of experimental design for risk assessment studies. Recent modeling work on examining the spread rates of gene drive systems in vertebrate pests shows that homing rates are an important characteristic of low-risk gene drive systems that confer high eradication probabilities of the pest species (Prowse et al. 2017). This work emphasizes that understanding factors that affect successful homing is a critical avenue for empirical research (Prowse et al. 2017). To date, models of gene drive systems have focused primarily on combined population genetic-dynamic models of a two-deme or island-mainland system (Dhole et al. 2018; Edgington and Alphey 2018; Sudweeks et al. 2019). However, individual-level spatial processes due to social structure or movement behavior, and mating structure, can have important 
consequences for structuring genetic variation in space, suggesting that these are important future directions for models and experiments to explore.

\section{Gene Drives: Risk Mitigation}

Several molecular strategies have been proposed to limit gene drive spread including physical separation of gene drive components ("split drive"; DiCarlo et al. 2015) or gene drives that only function above a certain population frequency threshold (Buchman et al. 2018; Leftwich et al. 2018). Engineering the system such that there is a marker gene could also be useful for monitoring containment (Beech et al. 2009). Less efficient drive systems will be easier to contain than highly efficient systems (Dhole et al. 2018). Thus, a clear understanding of the potential spread rates for particular drive mechanisms is crucial for evaluating containment risk (Dhole et al. 2018). Containment risk in a target area will depend on the demographic and spatial dynamics of the pest species within the target zone (Edgington and Alphey 2018; Wilkins et al. 2018) and its connectivity to surrounding nontarget populations. Because measuring this risk in the field is in itself risky, important preliminary steps are to understand the ecological risk landscape in silico using simulations and experimental data collected in a virtual environment under stringent confinement conditions (Abbasi 2016; Akbari et al. 2015).

Another promising approach capitalizes on the precise genome editing afforded by CRISPR-Cas systems to target locally unique sequences that are fixed in the population of interest (i.e., locally fixed alleles, LFA) but absent (or at low frequency) in nontarget populations (Campbell et al. 2019). Evidence suggests that a single nucleotide change in the proto-spacer adjacent motif (PAM) associated with a sgRNA target site can be sufficient to preclude endonuclease binding (Hsu et al. 2013). Thus, population specificity might be accomplished through designing sgRNA that bind genomic regions harboring polymorphisms that form a functional PAM site in the target populations, but not in nontarget populations. Recent modeling efforts (Sudweeks et al. 2019) demonstrate that such an approach can effectively achieve localized population suppression under a variety of scenarios. Interestingly, this work suggests that escape and interbreeding of gene-drive-bearing individuals out of the treatment area are likely to result in only transient suppression of nontarget populations, even when the "susceptible" (i.e., target) allele is present at high frequencies. This phenomenon is explained by the presence of "resistance" alleles (i.e., naturally occurring genetic variants that preclude gene drive homing) in nontarget populations that will be rapidly driven to high frequencies as a result of selection against drive-bearing individuals, subject to the assumptions of the model. This finding also emphasizes the critical importance of thorough population genetic evaluation of the target population prior to sgRNA design to identify sequences that are locally invariant, as even a low level of polymorphism would reduce effectiveness of gene-drive-mediated population suppression. Likewise, both recent theoretical (Unckless et al. 2017) and empirical studies (Champer et al. 2017) suggest that 
resistant alleles will inevitably arise spontaneously within populations from de novo mutations in the target site or by the gene drive itself as a consequence of errors in the cleavage repair process (e.g., NHEJ). One proposed solution to the evolution of resistance to gene drives is the design of drive systems with multiplexed sgRNA (Cong et al. 2013; Champer et al. 2018), that is, multiple sgRNA that each targets adjacent locally fixed alleles, wherein there is a low likelihood of resistance arising simultaneously in all targets. Indeed, evidence from modeling efforts suggests that multiplexed sgRNA is likely to be necessary for population suppression, even under low levels of NHEJ (Prowse et al. 2017).

The feasibility of the LFA strategy for gene drive containment in the context of vertebrate pest management will depend critically on several aspects of the population structure and ecological setting. As gene drive effectiveness will be diminished by the influx of resistant individuals, relatively isolated populations with low levels of gene flow to nontarget populations, such as oceanic islands, would provide ideal settings. Small populations of introduced species, which are often founded by a small number of individuals, are also expected to harbor reduced allelic diversity, thereby providing a greater number of potential locally fixed allele targets (Morgan et al. 2018). Overall, it is clear that the success of the LFA approach will depend on rigorous population genetic survey of allelic variation within the target population prior to any action.

\section{Impacts and Effectiveness}

The most straightforward measure of effectiveness of a pest control technique is to evaluate how rapidly it reduces the target pest population. However, determining the effects of control on the resources being protected relative to the effort invested is critical for choosing a technique with optimal effectiveness (Hone et al. 2017). Yet this "effort-outcomes relationship" is rarely reported or understood in vertebrate pest management (Hone et al. 2018). The effort-outcomes relationship not only highlights how much effort is needed for a desired outcome but also can reveal which techniques are optimal. It provides additional information over effectiveness alone for choosing between techniques because there may be multiple techniques with the same outcome but with drastically different effort levels. For GM organisms, once a technology is ready for application, there is potential for a much lower application cost than traditional methods (Herman et al. 2019), leading to a more favorable effort-outcome level relative to other techniques. Appropriately defining the dimensions of "effort" and "outcomes" in these comparisons is not straightforward, however, and is worthy of much consideration. For example, over what time scale do we measure outcomes? There may be downstream effects such as increased crop yield per hectare such that less land must be farmed to protect food security (Herman et al. 2019). This type of higher efficiency could also lead to lower farming effort over time, thus affecting a component of management effort (Herman et al. 2019). Lastly, the measure of effectiveness needs to be defined based on the 
management objective. For example, if we define our objective as maximum agricultural sustainability with the smallest ecological footprint, then the optimal technique, or measure of effectiveness, might be different than if we define our objective simply as maximum crop yield.

Another important component of outcomes is "side effects" or "impacts" of a control method. Impacts of GM organisms could be beneficial such as reduced carbon emissions (Herman et al. 2019) or reduced health hazards from chemical exposure. Alternatively, GM methods for pest control could alter the population genetics of an entire species, potentially causing unforeseen impacts on ecosystem function and stability. Defining and quantifying impacts are as complicated as defining effectiveness and require a systematic decision framework for risk assessment involving multiple stakeholders (Sanvido et al. 2012).

\section{Regulatory Framework in the United States}

A new era of genetic modification began in the 1970s with the generation of a new plasmid from DNA segments of two distinct plasmid species that was inserted into a bacterium (Escherichia coli) (Cohen et al. 1973). Questions soon arose regarding whether products derived from the new genetically modified organisms (GMOs) would pose greater risks than those products achieved through traditional techniques and whether the regulatory mechanisms were sufficient evaluate safety.

The distribution and use of almost all chemical and biological wildlife damage control products used to protect agriculture or to control invasive species are regulated under a set of US federal statutes under the jurisdiction of one or more federal regulatory agencies. The three agencies that have regulatory authority over biotechnology products in the United States are the Food and Drug Administration (FDA), the Environmental Protection Agency (EPA), and the United States Department of Agriculture (USDA). These regulatory agencies have oversight of a broad spectrum of products, including GMOs, and subscribe to risk-based assessments to ensure human and environmental health. In some instances, the agency responsible for the regulation of a specific product is uncertain and requires a multiagency conference and decision as to the most appropriate agency or agencies best suited to provide regulatory oversight. Regulatory agencies sometimes have overlapping jurisdictions for a single product. Both of these situations may cause confusion and frustration for both the public and the regulated community and lead to a lack of confidence in the processes.

In an effort to stem these concerns, the US White House Office of Science and Technology Policy (OSTP) formed a workgroup in 1984 to assess the existing regulatory mechanisms for their capability to ensure safety while also fostering a supportive environment for technological development of new biotechnology products. The OSTP released the "Coordinated Framework for Regulation of Biotechnology" in 1986 (OSTP 1986). The Coordinated Framework concluded that the existing laws address most health and safety regulatory processes for biotechnology 
products. Further, the existing laws provide immediate regulatory oversight for the biotechnology industry, and the implementation of new laws would create uncertainty disruptive to the advancement of new technologies and thus be counterproductive.

The Coordinated Framework was updated in 1992 to explain the federal regulatory agencies' oversight roles and responsibilities as provided by statute, describe a science-based risk assessment process for oversight of biotechnology products released into the environment, and reaffirm that the regulatory oversight will focus "on the characteristics of the biotechnology product and the environment into which it is being introduced" and not whether the process employed to create the product is safe (Bromley 1992).

Federal regulatory agencies were directed by the Executive Office of the President in 2015 to further clarify their roles and responsibilities and to develop a strategy to ensure the regulatory processes are adaptable to scientific advances leading to new types of products. The Emerging Technologies Interagency Policy Coordination Committee Biotechnology Working Group was formed to develop the strategy and update the Coordinated Framework. The result was the National Strategy for Modernizing the Regulatory System for Biotechnology Products was released in 2016 (OSTP 2019). The Strategy's priorities are to increase transparency, increase predictability and efficiency, and support the science that underpins the regulatory system. The goals of the updated Coordinated Framework, issued in 2017, were to increase public understanding and confidence in the regulatory system and "to prevent unnecessary barriers to innovation and competitiveness." The statutory authorities and roles of the FDA, EPA, and USDA were again reaffirmed (OSTP 2016, 2017).

The FDA has broad statutory authority under the Federal Food, Drug, and Cosmetic Act (FDCA) over human food and animal feed including pesticide residues, drugs, cosmetics, and biological products. Genetically engineered animals are regulated under the drug provisions with exceptions including GMO mosquitoes intended only for mosquito population control. Drugs are defined in statue as "articles (other than food) intended to affect the structure or any function of the body of man or other animals" (21 CFR § 321).

Early research in vertebrate species focused on the genetic modification of domestic animals for the production of human drugs. This precedent formed a natural fit for FDA to regulate all genetically engineered animals irrespective of the genetic alteration. Other genetically engineered organisms regulated under the FDCA are human and animal foods derived from non-pesticidal GM plants and human drugs, biological products, and medical devices derived from GE sources. It is important to note that FDA regulates the genetic construct and not the animal itself.

All pesticides registered, distributed, and used in the United States are regulated by EPA under the Federal Insecticide, Fungicide, and Rodenticide Act (FIFRA). The EPA definition of a pesticide is "any substance (or group of structurally similar substances if specified by the Agency) that will prevent, destroy, repel or mitigate any pest, or that functions as a plant regulator, desiccant, or defoliant..." with specific exceptions provided in $40 \mathrm{CFR} \S 174.3$. Under this authority, EPA regulates 
three major classes of pesticides: conventional, microbial, and biopesticides. Historically, all pesticides were regulated under a single framework. In time, microbial pesticides and biopesticides were split from conventional pesticides, and each is now regulated under their own respective requirements more suited to their formulations and uses. GMO pesticides include microbes modified to produce a pesticide, crops tolerant to specific herbicides, plant-incorporated protectants (PIP) that express pesticidal properties, and most recently mosquitoes genetically engineered to control a pest. In addition to FIFRA, EPA has authority to regulate the allowable level of pesticide residues allowed in food and feed under the FDCA.

Several agencies within the USDA exercise authority over certain plants and animals, food and feed, and products intended to mitigate plant and animal disease, all of which may include biotechnology products. The USDA's statutory authority is provided by the Plant Protection Act (PPA, Public Law 106-224), Animal Health Protection Act (AHPA, Pub. L. 107-171, 116 Stat. 494, 7 U.S.C. 8301), and the Virus-Serum-Toxin Act (VSTA, 21 USC 151-159). The USDA Animal and Plant Health Inspection Service (APHIS) has regulatory oversight under PPA and AHPA over biotechnology products that are considered plant pests or noxious weeds and livestock pests including but not limited to those that cause disease. The USDA Center for Veterinary Biologics has regulatory authority under VSTA over veterinary biological products to prevent, diagnose, and treat disease in animals. Several other statutes are administered by the USDA Food Safety and Inspection Service (FSIS).

In summary, primary regulatory authority is determined by how the various federal laws define the different classes of products, which is based on their intended use, composition, route of administration, and mechanism of action rather than the technology used to create them (Ruell et al. 2016; OSTP 2017; Wozniak 2018). These regulatory laws also encompass completely novel biotechnologies or novel uses of existing technologies that alter the structure or function of organisms, unless they have already been specifically exempted by law or agency rulemaking (OSTP 2017; Wozniak 2018). All three of the federal agencies have shared roles and responsibilities that require coordination (Table 1). In particular, the USDA and FDA often coordinate due to overlapping jurisdiction, but development of these newer technologies emphasizes the challenges for regulatory agencies to adapt existing regulatory frameworks to this changing technological landscape.

The different agencies charged with regulating these products have developed different sets of standards and requirements based on the particularities of the underlying laws they are charged with implementing (Ruell et al. 2016; OSTP 2017). Therefore, early knowledge of a potential product's regulatory situation is crucial for researchers when determining the feasibility of gaining authorization for the product and in order to comply with and meet the relevant regulatory requirements during the research and development phase. Any field testing of experimental products usually requires some form of authorization from the agency with primary regulatory jurisdiction. In addition, notification and authorization are also often required prior to importing, exporting, or interstate transporting of experimental 
Table 1 Summary of pesticide category, claims, characteristics, and application method

\begin{tabular}{|c|c|c|c|}
\hline Product category & Product claim & Product characteristics & Application method \\
\hline \multirow{5}{*}{$\begin{array}{l}\text { Vertebrate animal } \\
\text { with intentionally } \\
\text { altered genomic } \\
\text { DNA }\end{array}$} & \multirow{5}{*}{$\begin{array}{l}\text { Population control/ } \\
\text { eradication of a target } \\
\text { vertebrate pest through } \\
\text { reproduction of the edited } \\
\text { animal with wild } \\
\text { individuals to produce } \\
\text { predominantly male, } \\
\text { infertile, inviable, or } \\
\text { reduced fitness offspring }\end{array}$} & $\begin{array}{l}\text { Derived from } \\
\text { vertebrate pest species }\end{array}$ & \multirow{5}{*}{$\begin{array}{l}\text { Environmental } \\
\text { release of live } \\
\text { individuals to breed } \\
\text { with target vertebrate } \\
\text { pest }\end{array}$} \\
\hline & & $\begin{array}{l}\text { Edited to sire } \\
\text { predominantly male, } \\
\text { infertile, or inviable } \\
\text { offspring }\end{array}$ & \\
\hline & & $\begin{array}{l}\text { With or without gene } \\
\text { drive }\end{array}$ & \\
\hline & & $\begin{array}{l}\text { Vertebrate pest is native } \\
\text { or invasive }\end{array}$ & \\
\hline & & $\begin{array}{l}\text { Not a pest under the } \\
\text { Livestock Health } \\
\text { Protection Act (LHPA) }\end{array}$ & \\
\hline \multirow{9}{*}{$\begin{array}{l}\text { Invertebrate } \\
\text { animal with } \\
\text { intentionally } \\
\text { altered genomic } \\
\text { DNA }\end{array}$} & \multirow[t]{5}{*}{$\begin{array}{l}\text { Repel/kill/contracept a } \\
\text { target vertebrate pest }\end{array}$} & $\begin{array}{l}\text { Edited to produce the } \\
\text { product (a substance) }\end{array}$ & \multirow{4}{*}{$\begin{array}{l}\text { Environmental } \\
\text { release of the live } \\
\text { invertebrates to be } \\
\text { consumed by target } \\
\text { vertebrate pest (oral } \\
\text { application) }\end{array}$} \\
\hline & & $\begin{array}{l}\text { Product is not } \\
\text { harvested, but rather is } \\
\text { applied as a release of } \\
\text { the live invertebrate }\end{array}$ & \\
\hline & & $\begin{array}{l}\text { Not a pest under the } \\
\text { LHPA }^{\text {a }}\end{array}$ & \\
\hline & & \multirow[t]{2}{*}{$\begin{array}{l}\text { Not a plant pest under } \\
\text { the Plant Protection Act } \\
(\mathrm{PPA})^{\mathrm{a}}\end{array}$} & \\
\hline & & & $\begin{array}{l}\text { Oral application of } \\
\text { dead invertebrate }\end{array}$ \\
\hline & & $\begin{array}{l}\text { Edited to produce the } \\
\text { product (a substance) }\end{array}$ & \multirow{4}{*}{$\begin{array}{l}\text { Oral, dermal, } \\
\text { inhalation } \\
\text { application to target } \\
\text { vertebrate pest }\end{array}$} \\
\hline & & $\begin{array}{l}\text { Product is harvested } \\
\text { from and applied apart } \\
\text { from the invertebrate } \\
\text { itself }\end{array}$ & \\
\hline & & $\begin{array}{l}\text { Not a pest under the } \\
\text { LHPA }^{\mathrm{a}}\end{array}$ & \\
\hline & & $\begin{array}{l}\text { Not a plant pest under } \\
\text { the PPA }\end{array}$ & \\
\hline \multirow[t]{3}{*}{$\begin{array}{l}\text { Modified } \\
\text { bacterium or } \\
\text { fungus }\end{array}$} & \multirow[t]{3}{*}{ Kill a target vertebrate pest } & $\begin{array}{l}\text { Designed to cause } \\
\text { disease (target- } \\
\text { specific) in a } \\
\text { vertebrate pest }\end{array}$ & \multirow[t]{3}{*}{$\begin{array}{l}\text { Oral, dermal, } \\
\text { inhalation } \\
\text { application to target } \\
\text { vertebrate pest }\end{array}$} \\
\hline & & $\begin{array}{l}\text { Not a pest under the } \\
\text { LHPA }^{\text {a }}\end{array}$ & \\
\hline & & $\begin{array}{l}\text { Not a plant pest under } \\
\text { the PPA }\end{array}$ & \\
\hline
\end{tabular}


Table 1 (continued)

\begin{tabular}{l|l|l|l}
\hline Product category & Product claim & Product characteristics & Application method \\
\hline $\begin{array}{l}\text { Substance causing } \\
\text { RNA interference }\end{array}$ & $\begin{array}{l}\text { Kill or contracept a target } \\
\text { vertebrate pest }\end{array}$ & $\begin{array}{l}\text { Designed to cause } \\
\text { degradation of mRNA } \\
\text { and prevent translation } \\
\text { of a specific protein } \\
\text { target-specific) within } \\
\text { the target vertebrate } \\
\text { pest }\end{array}$ & $\begin{array}{l}\text { Oral, dermal, } \\
\text { inhalation } \\
\text { application to target } \\
\text { vertebrate pest }\end{array}$ \\
\hline $\begin{array}{l}\text { Nanomachines } \\
\text { with pesticides }\end{array}$ & $\begin{array}{l}\text { Kill or contracept a target } \\
\text { vertebrate pest }\end{array}$ & $\begin{array}{l}\text { Toxicant or } \\
\text { contraceptive } \\
\text { combined with } \\
\text { nanorobotics (delivery } \\
\text { device) }\end{array}$ & $\begin{array}{l}\text { Oral or inhalation } \\
\text { application to target } \\
\text { vertebrate pest }\end{array}$ \\
\hline $\begin{array}{l}\text { Substance causing } \\
\text { change in sensory } \\
\text { organ perception } \\
\text { or ill feeling }\end{array}$ & $\begin{array}{l}\text { Repel a target vertebrate } \\
\text { pest from the food, forage, } \\
\text { or prey through aversive } \\
\text { conditioning }\end{array}$ & $\begin{array}{l}\text { Causes unpleasant to } \\
\text { sensory feedback or } \\
\text { function, or causes } \\
\text { sickness when } \\
\text { combined with } \\
\text { normally attractive } \\
\text { foods, forage, or prey }\end{array}$ & $\begin{array}{l}\text { Oral, dermal, } \\
\text { inhalation } \\
\text { application to target } \\
\text { vertebrate pest }\end{array}$ \\
\hline $\begin{array}{l}\text { Device combined } \\
\text { with a substance } \\
\text { that causes } \\
\text { infertility }\end{array}$ & $\begin{array}{l}\text { Contracept a target } \\
\text { vertebrate pest }\end{array}$ & Contraceptive & $\begin{array}{l}\text { Insertion into a } \\
\text { female reproductive } \\
\text { body cavity }\end{array}$ \\
\hline
\end{tabular}

${ }^{a}$ Would not fall under USDA APHIS regulatory authority

products. Conventional wildlife damage products with clear regulatory precedents are relatively easy to classify under the different regulatory jurisdictions.

\section{Regulatory Framework: Gene Silencing Using RNAi}

The regulatory framework for the new generation of RNAi-based pesticides would likely follow the general guidelines for biopesticides, which are modified from conventional pesticides (OSTP 1986). If applied to growing crops, the FDA ensures the food from crops containing RNAi is as safe as its conventional counterpart. The USDA ensures there is no risk to agriculture from the use of RNAi. The EPA ensures that the product can perform its intended function with a reasonable certainty of no harm to people from dietary and residential exposure and no unreasonable risks to the environment. 


\section{Regulatory Framework: Gene Editing}

Regulatory jurisdiction of novel GM products for wildlife damage control can be more difficult to classify and may require prolonged consultation between the regulatory agencies themselves before a final designation is made. As an example, products consisting of microorganisms or invertebrates, whether unmodified or modified (including GM), which are used to change the structure or function of animals, have been on the market for some time, and, for the most part, are now distributed among the regulatory agencies (Wozniak et al. 2012; Ruell et al. 2016; FDA CVM 2017a, b; OSTP 2017; EPA OPP 2018; Wozniak 2018). They are regulated by USDA based on whether they qualify as a pest to livestock as defined by the AHPA or as a veterinary biologic as defined by VSTA. They are regulated by EPA if they or their byproducts are used as pesticides against pests as defined by FIFRA. Any other product that uses microorganisms with the intent to directly change the structure or function of animals is regulated by FDA.

In contrast, products consisting of vertebrate animals fall into much different regulatory classifications that are not as clear cut. Non-GM vertebrate animals released to control a pest species, aka biological control agents (e.g., the release of mongooses to control rats on islands), do not qualify as products requiring authorization under the FDCA and have been exempt from the registration requirements of FIFRA by EPA (40 C.F.R. $§ 152.20(a)(3)$ ). However, EPA has left the door open to revoke this exemption for any biological control agent it considers to be inadequately regulated by other federal agencies (40 C.F.R. $\S 152.20(a)(2)$ ). In contrast, GM vertebrate animals do fall under the provisions of the FDCA, or more accurately, the intentionally altered genomic DNA within the GM animal becomes the regulated article because it changes the structure of function of the animal for an intended purpose (FDA CVM 2015, 2017a; OSTP 2017). This intentionally altered genomic DNA in a GM vertebrate animal is not currently classified as a regulated article under the AHPA, VSTA, or FIFRA, although a substance produced by a GM vertebrate animal could be regulated separately by another agency if it meets their definition of a regulated article (FDA CVM 2015; Ruell et al. 2016; FDA CVM 2017a). Several GM vertebrate animal products have made their way through part of or the whole approval process with FDA to date (e.g., GE salmon, chickens, goats), although none so far were designed for use in wildlife damage control or pest management (EPA OPP 2018).

It is possible that the Congress or FDA and EPA may one day determine that certain GM vertebrate animals intended for population control of vertebrate pests will be classified as pesticides and regulated under FIFRA instead of under the provisions of the FDCA, similar to GM mosquitos intended solely for mosquito population control (FDA CVM 2017b). The two agencies have started working together to determine statutory authority over these types of GM animal products for pest management on the horizon, but it is unclear whether this will change their regulatory jurisdiction in the near future (EPA OPP 2018). Until alternative guidance is issued by FDA and EPA, the primary regulatory authority over all GM vertebrate 
animals will remain FDA (FDA CVM 2017a; OSTP 2017). FDA will work closely with EPA and other federal regulatory agencies charged with implementing environmental laws before authorizing any experimental field use or eventual approval of these novel products (FDA CVM 2017a). FDA recommends that product developers contact them early in the development phase of product development of GM vertebrates (FDA CVM 2017a).

There can be significant disadvantages for developers submitting the first product of its kind to a regulatory agency that result in unforeseen delays and costs prior to authorization. Many agencies, including EPA, will convene Scientific Advisory Panels at the expense of the applicant to help them determine how to appropriately evaluate the risk of the novel product type and the appropriate set of regulatory data they will require from the registrant prior to authorization (EPA OPP 2018). Once the agency's risk assessment process has been determined, study guidelines must then be developed and finalized for each data requirement. However, they will not usually initiate these processes until after they receive an application or information on an actual product, because these processes take considerable time and resources.

There is also the potential that a novel product could change regulatory hands midstream in the regulatory authorization process or even after a product has been authorized by an agency, like what happened with GE mosquitos used for mosquito population control, and this can pose additional difficulties and added costs for the applicant. For example, data that were collected or contracted for one authorization process may not be directly applicable or adequate for the next. The manufacturing and National Environmental Policy Act requirements for the product also differ depending on the agency and regulatory statute. Some regulatory statutes allow government agencies to take products through the full authorization process, and some require a private or nonprofit entity to be the applicant. Thus, last minute changes to the regulatory jurisdiction of a product can result in considerable challenges for the product developer in predicting the practicality and use timeline for novel products such as GM vertebrate animals used in animal damage control.

\section{Translational Product Development}

Translational product development can be thought of as a pipeline or continuum as an idea moves from research and development to fully implemented product or technique. Figure 1 graphically illustrates that pipeline for a regulated product. Early in the process, pilot and confirmatory development steps are undertaken to provide the information needed to assess the product development costs, market potential, and ultimately the viability of the product. Early in the product development pipeline, decisions are normally made regarding protecting intellectual property and the need to form development and commercialization partnerships. In the case of regulated products such as a pesticide, biologic, vaccine, or drug, a realistic assessment must be made as to the cost of regulatory studies and the time it will take 


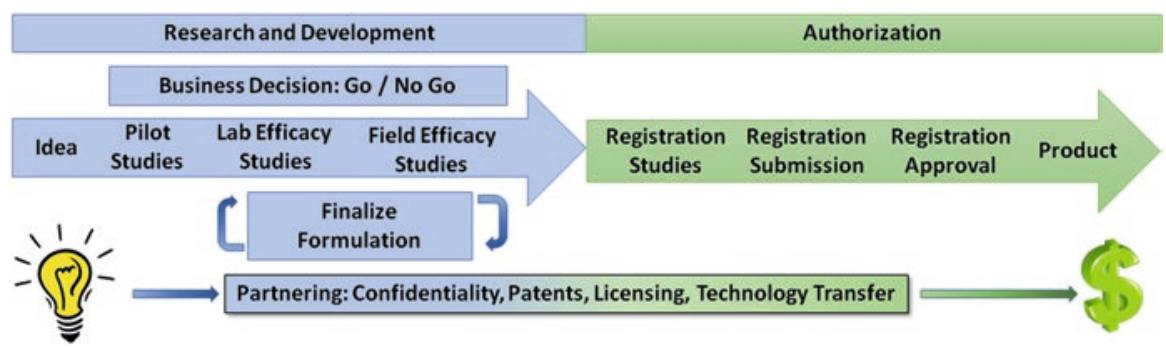

Fig. 1 Conceptual product development pipeline for regulated products developed in a federal laboratory

to obtain a product authorization. All of these aspects inform decisions in advancing development efforts.

As this chapter outlines, developments in our ability to manipulate or target the genetic code of an organism have opened up an entirely new world for product development. The application of genetic tools appears to be boundless in advancing medical, agricultural, and conservation goals. At the heart of biotechnology product development is the decision and ability to protect the intellectual property. To illustrate this, two potential biotech techniques or tools that will prove useful in agricultural production and conservation will be briefly presented. Both of these technologies, gene silencing and gene editing, share the same general product development pipeline but have significant variations along that path.

\section{Intellectual Property Protection}

At the heart of translational product development is technology transfer and, if appropriate, protection of intellectual property. There are many definitions of technology transfer, but in essence, it is the process by which technology or knowledge developed in one place or for one purpose is applied in and used in another place (FLC 2006). Two conditions are responsible for initiating or accomplishing technology transfer, a technology is created and pushed into practice, or some identified need creates the opportunity for a new technology. Regardless of what initiated the product development effort, the successful transfer from development to practice is the goal. An idea, technique, or tool is underutilized until it is put into practice.

Patent protection from the US Patent and Trademark Office or other international patent authorities can be a major driver of technology transfer. Patent protection allows the patent owner to exclusively pursue the development of the patented tool or technique or to license the rights to practice the patent to another entity, typically for a fee. As advances in genetic technologies allowed us to sequence genomes and identify specific genome sequences that were responsible for specific physiological functions, scientists and businesses sought patent protection of gene sequences they had identified in the hopes of capitalizing on those discoveries and future 
applications of that knowledge. The idea of patenting naturally occurring genetic code quickly became a hotly debated topic. Many found the idea of "owning" the knowledge of a person's genetic code unethical. Despite the debate, 4300 patents were issued for the human genome alone prior to 2013. In 2012, the US Supreme Court ruled that DNA in its natural form cannot be patented; however, DNA manipulated in a lab is eligible to be patented because DNA sequences altered by humans are not found in nature (NIH 2017, 2019; SCOTUS 2013). While this ruling closed the door on capitalizing on a person's genetic code, it defined what was allowed to be patented and provides the guidance for those seeking intellectual property protection for intentionally modified genetic tools.

\section{Intellectual Property: Gene Silencing Using RNAi}

As previously described, the ability to intentionally prevent or inhibit normal RNA translation has profound impacts on an organism's physiological function and has enormous potential to be utilized in human medicine, agricultural production, and many other beneficial areas. An example of a gene-silencing tool for agricultural protection is the development of new pest management tools, such as active ingredients used in pesticides. Typical pesticides function by disrupting a biochemical mechanism critical to life. Common biochemical mechanisms include, but are not limited to, cholinesterase inhibitors, which function by inhibiting nerve impulse transmission across synaptic junctions, and other pesticides disrupt the production of ATP by impacting enzyme production critical to normal Krebs cycle functions. Gene silencing could target similar critical functions but at the genetic level, by introducing engineered strands of RNA into the cell, which disrupt translation or transcription processes.

Taking advantage of an organism's unique genetic code could potentially lead to the development of species-specific, humane pesticides with reduced risk of unintended environmental or human health consequences. Such an approach could revolutionize pest management, leading to dramatic advances in agricultural and human health protection, and associated economic benefits to protected resources in addition to significant economic benefits to companies advancing these technologies. For these reasons, there will be a great desire to protect the intellectual property behind the technologies. Patenting is available for gene-silencing tools because the patented technology would not be based on the native genetic code or an organism, but rather on the man-made genetic sequences introduced into cells which disrupt normal RNA translation or transcription processes. In the case of pest management, most of these types of products would be regulated as pesticides by the US EPA. Consequently, there is clear understanding of the regulatory path these products would face. Even though this line of product development is high risk, having regulatory clarity paves the way for clear product development efforts. 


\section{Intellectual Property: Gene Editing}

Directly editing the genetic sequence of an organism has the potential for significant contributions to agriculture, human health, and natural resource protection. As described above, the discovery of native CRISPR-Cas systems and the knowledge of how to utilize these systems to make specific gene edits have revolutionized our ability to produce single-generation designer organisms. Current lines of research are focused on developing gene-edited organisms that pass the desired trait to a high proportion of their offspring in a way that it is active in subsequent generations, known as "gene drive" systems. Driving a trait through a population has enormous social implications and elicits very controversial discussions, especially when it could be applied to natural resource conservation issues. Despite those important discussions, work will continue to develop applications of gene-edited and gene drive organisms because associated economic benefits are presumed to be high. If the resulting products include unnatural genetic sequences in an organism, there is a potential for seeking patent protection.

The decision to protect intellectual property is only one step of the technology transfer pipeline. The ultimate proof that product development efforts were successful is seeing that technology adopted somewhere in society. However, an important consideration is that the ultimate landing place of a technology may not be what the original researchers and product developers intended.

\section{Future Directions}

Wildlife damage conflicts continue to increase as the world's population increases. Generally speaking, mitigation of a conflict implies an active management or control program. Typically, conflicts manifest themselves as invasive species and disease impacts on native ecosystems and damage caused by wildlife to commodities of value to humans (e.g., agriculture, property, health, safety, property). Managers must weigh the options available to them to mitigate the conflict in terms of economics, effectiveness, environmental effects, and humaneness, all within a social framework. A question becomes whether today's technologies will be well suited to constraints and problems we may face into the future. For example, will today's reliance on chemical pesticides continue into the future, and if not, what mitigation tools and strategies will replace these methods? Like many new technologies that were introduced in the past, there is great promise and apprehension about these new genetically based methods in terms of development and use. Herein, we reviewed the context, opportunities, and challenges of genetically based biopesticides and provided some social, technical, and regulatory practicalities in research and development for technologies such as gene silencing and gene drives. The encouraging news is that the scope and depth of discussions are vigorous and 
inclusive (e.g., scientists, ethicists, managers, regulators, the public, and policy makers), all of which bodes well for informed decision processes.

Acknowledgments This work was supported in part by the US Department of Agriculture's Animal and Plant Health Inspection Service. The findings and conclusions in this publication are those of the authors and should not be construed to represent any official USDA or US Government determination or policy.

\section{References}

Abbasi J (2016) National Academies hit the brakes on gene drive-modified organisms. JAMA 316:482-483. https://doi.org/10.1001/jama.2016.8830

Adler GH, Levins R (1994) The island syndrome in rodent populations. Q Rev Bio 69:473-490

Ahmadzada T, Reid G, McKenzie DR (2018) Fundamentals of siRNA and miRNA therapeutics and a review of targeted nanoparticle delivery systems in breast cancer. Biophys Rev 10:69-86

Akbari OS, Bellen HJ, Bier E, Bullock SL, Burt A, Church GM, Cook KR, Duchek P, Edwards OR, Esvelt KM, Gantz VM (2015) Safeguarding gene drive experiments in the laboratory. Science 349:927-929. https://doi.org/10.1126/science.aac7932

Alexopoulou L, Holt AC, Medzhitov R, Flavell RA (2001) Recognition of double-stranded RNA and activation of NF-kB by toll-like receptor 3. Nature 413:732

Allan JR, Watson JE, Di Marco M, O’Bryan CJ, Possingham HP, Atkinson SC, Venter O (2019) Hotspots of human impact on threatened terrestrial vertebrates. PLoS Biol. https://journals. plos.org/plosbiology/article?id=10.1371/journal.pbio. 3000158

Alphey L (2014) Genetic control of mosquitoes. Annu Rev Entomol 59:205-224

Amarzguioui M, Holen T, Babaie E, Prydz H (2003) Tolerance for mutations and chemical modifications in a siRNA. Nucleic Acids Res 31:589-595

Avila LA, Aps LR, Ploscariu N, Sukthankar P, Guo R, Wilkinson KE, Games P, Szoszkiewicz R, Alves RPS, Diniz MO, Fang Y (2016) Gene delivery and immunomodulatory effects of plasmid DNA associated with branched Amphiphilic peptide capsules. J Control Release 241:5-24

Backus GA, Gross K (2016) Genetic engineering to eradicate invasive mice on islands: modeling the efficiency and ecological impacts. Ecosphere 7. https://doi.org/10.1002/ecs2.1589

Ball RL, Bajaj P, Whitehead KA (2018) Oral delivery of siRNA lipid nanoparticles: fate in the GI tract. Sci Rep 8:2178

Barrangou R (2015) The roles of CRISPR-Cas systems in adaptive immunity and beyond. Curr Opin Immunol 32:36-41

Barrangou R, Doudna JA (2016) Applications of CRISPR technologies in research and beyond. Nat Biotechnol 34:933

Baum JA, Roberts JK (2014) Progress towards RNAi-mediated insect Pest management. In: Dhadialla TS, Gill SS (eds) Advances in insect physiology. Academic Press, New York, pp 249-295

Beech CJ, Nagaraju J, Vasan SS, Rose RI, Othman RY, Pillai V, Saraswathy TS (2009) Risk analysis of a hypothetical open field release of a self-limiting transgenic Aedes aegypti mosquito strain to combat dengue. APJMBB 17:97-108

Benedict MQ, Burt A, Capurro ML, De Barro P, Handler AM, Hayes KR, Marshall JM, Tabachnick WJ, Adelman ZN (2018) Recommendations for laboratory containment and management of gene drive systems in arthropods. Vector-Borne Zoonotic Dis 18:2-13. https://doi.org/10.1089/ vbz.2017.2121

Bromley A (1992) Exercise of federal oversight within scope of statutory authority: planned introductions of biotechnology products into the environment. White house, Office of Science and technology policy (OSTP). Fed Regist 57:6753-6762 
Buchman AB, Ivy T, Marshall JM, Akbari OS, Hay BA (2018) Engineered reciprocal chromosome translocations drive high threshold, reversible population replacement in Drosophila. ACS Synthc Bio 7:1359-1370

Burand JP, Hunter WB (2013) RNAi: future in insect management. J Invertebr Path 112:S68-S74

Burt A (2003) Site-specific selfish genes as tools for the control and genetic engineering of natural populations. Proc R Soc Lond B Biol Sci 270:921-928

Campbell KJ, Beek J, Eason CT, Glen AS, Godwin J, Gould F, Holmes ND, Howald GR, Madden FM, Ponder JB, Threadgill DW (2015) The next generation of rodent eradications: innovative technologies and tools to improve species specificity and increase their feasibility on islands. Biol Conserv 185:47-58

Campbell KJ, Saah JR, Brown PR, Godwin J, Gould F, Howald GR, Piaggio A, Thomas P, Tompkins DM, Threadgill D, Delborne J, Kanavy DM, Kuiken T, Packard H, Serr M, Shiels A (2019) A potential new tool for the toolbox: assessing gene drives for eradicating invasive rodent populations. In: Veitch CR, Clout MN, Martin AR, Russell JC, West CJ (eds) Island invasives: scaling up to meet the challenge, Occasional Paper SSC no. 62. IUCN, Gland, pp 6-14

Carlson RH (2010) Biology is technology. Harvard University Press, Cambridge, p 288

Champer J, Buchman A, Akbari OS (2016) Cheating evolution: engineering gene drives to manipulate the fate of wild populations. Nat Rev Genet 17:146-159

Champer J, Reeves R, Oh SY, Liu C, Liu J, Clark AG, Messer PW (2017) Novel CRISPR/Cas9 gene drive constructs reveal insights into mechanisms of resistance allele formation and drive efficiency in genetically diverse populations. PLoS Genet 13(7). https://doi.org/10.1371/journal.pgen.1006796

Champer J, Liu J, Oh SY, Reeves R, Luthra A, Oakes N, Clark AG, Messer PW (2018) Reducing resistance allele formation in CRISPR gene drive. PNAS 115:5522-5527

Church GM, Regis E (2012) Regenesis: how synthetic biology will reinvent nature and ourselves. Basic Books, New York, p 284

Cohen SN, Chang AC, Boyer HW, Helling RB (1973) Construction of biologically functional bacterial plasmids in vitro. PNAS 70:3240-3244. https://doi.org/10.1073/pnas.70.11.3240

Collins JP (2018) Gene drives in our future: challenges of and opportunities for using a selfsustaining technology in pest and vector management. BMC Proc 12:9. https://doi.org/10.1186/ s12919-018-0110-4

Cong L, Ran FA, Cox D, Lin S, Barretto R, Habib N, Hsu PD, Wu X, Jiang W, Marraffini LA, Zhang F (2013) Multiplex genome engineering using CRISPR/Cas systems. Science 339:819-823

Conklin BR (2019) On the road to a gene drive in mammals. Nature 566:43-45. https://doi. org/10.1038/d41586-019-00185-y

Conover MR (2001) Resolving human-wildlife conflicts: the science of wildlife damage management. CRC press, New York

Courtier-Orgogozo V, Morizot B, Boëte C (2017) Agricultural pest control with CRISPRbased gene drive: time for public debate. EMBO Rep 18:878-880. https://doi.org/10.15252/ embr.201744205

Crick F (1970) Central dogma of molecular biology. Nature 227:561

Cuthbert RJ, Visser P, Louw H, Rexer-Huber K, Parker G, Ryan PG (2011) Preparations for the eradication of mice from Gough Island: results of bait acceptance trials above ground and around cave systems. Wildl Res 38:196-203

Cuthbert RJ, Wanless RM, Angel A, Burle MH, Hilton GM, Louw H, Visser P, Wilson JW, Ryan PG (2016) Drivers of predatory behavior and extreme size in house mice Mus musculus on Gough Island. J Mammal 97:533-544

Czauderna F, Fechtner M, Dames S, AyguÈn H, Klippel A, Pronk GJ, Giese K, Kaufmann J (2003) Structural variations and stabilising modifications of synthetic siRNAs in mammalian cells. Nucleic Acids Res 31:2705-2716

Damalas CA, Eleftherohorinos IG (2011) Pesticide exposure, safety issues, and risk assessment indicators. Int J Environ Res Public Health 8:1402-1419 
Dhole S, Vella MR, Lloyd AL, Gould F (2018) Invasion and migration of spatially self-limiting gene drives: a comparative analysis. Evol Appl 11:794-808. https://doi.org/10.1111/eva.12583

DiCarlo JE, Chavez A, Dietz SL, Esvelt KM, Church GM (2015) Safeguarding CRISPR-Cas9 gene drives in yeast. Nat Biotechnol 33:1250-1255

Doherty TS, Glen AS, Nimmo DG, Ritchie EG, Dickman CR (2016) Invasive predators and global biodiversity loss. PNAS 113:11261-11265

Doudna JA, Charpentier E (2014) The new frontier of genome engineering with CRISPR-Cas9. Science 346:1258096

Eason CT, Fagerstone KA, Eisemann JD, Humphrys S, O’Hare JR, Lapidge SJ (2010) A review of existing and potential New World and Australasian vertebrate pesticides with a rationale for linking use patterns to registration requirements. Int J Pest Manag 56:109-125

Edgington MP, Alphey LS (2018) Population dynamics of engineered underdominance and killer-rescue gene drives in the control of disease vectors. PLOS Comput Bio 14. https://doi. org/10.1371/journal.pcbi.1006059

Elbashir SM, Martinez J, Patkaniowska A, Lendeckel W, Tuschl T (2001) Functional anatomy of siRNAs for mediating efficient RNAi in Drosophila melanogaster embryo lysate. EMBO J 20:6877-6888

EPA OPP (2018) U.S. Environmental Protection Agency, Office of Pesticide Programs, November 1. Biotechnology/Emerging Technologies Seminar. https://register.gotowebinar.com/ register/6494848564946662914

Esvelt KM, Smidler AL, Catteruccia F, Church GM (2014) Emerging technology: concerning RNA-guided gene drives for the alteration of wild populations. elife 3. https://doi.org/10.7554/ eLife.03401

FDA CVM (2015) U.S. Food and Drug Administration, Center for Veterinary Medicine, June. \#187 Guidance for industry on regulation of genetically engineered animals containing heritable recombinant DNA constructs. https://wayback.archive-it.org/7993/20170111005939/ http://www.fda.gov/downloads/AnimalVeterinary/GuidanceComplianceEnforcement/ GuidanceforIndustry/UCM113903.pdf

FDA CVM (2017a) U.S. Food and Drug Administration, Center for Veterinary Medicine, January. Draft Guidance: \#187 Guidance for industry on regulation of intentionally altered genomic DNA in animals. http://www.fda.gov/downloads/AnimalVeterinary/ GuidanceComplianceEnforcement/GuidanceforIndustry/UCM113903.pdf

FDA CVM (2017b) U.S. Food and Drug Administration, Center for Veterinary Medicine, October. \#236 Clarification of FDA and EPA Jurisdiction Over Mosquito-Related Products. https://www.fda.gov/downloads/AnimalVeterinary/GuidanceComplianceEnforcement/ GuidanceforIndustry/UCM533600.pdf

Ferguson NM (2018) Challenges and opportunities in controlling mosquito-borne infections. Nature 559:490. https://doi.org/10.1038/s41586-018-0318-5

Fire A, Xu S, Montgomery MK, Kostas SA, Driver SE, Mello CC (1998) Potent and specific genetic interference by double-stranded RNA in Caenorhabditis elegans. Nature 391:806

FLC (2006) FLC technology transfer desk reference: a comprehensive introduction to technology transfer. Federal Laboratory Consortium for Technology Transfer, Cherry Hill, NJ. http://ictt. by/Rus/Portals/0/T2_Desk_Reference_2006.pdf

Gantz VM, Bier E (2015) The mutagenic chain reaction: a method for converting heterozygous to homozygous mutations. Science 348:442-444

Gantz VM, Jasinskiene N, Tatarenkova O, Fazekas A, Macias VM, Bier E, James AA (2015) Highly efficient Cas9-mediated gene drive for population modification of the malaria vector mosquito Anopheles stephensi. PNAS 112:E6736-E6743

Gemmell NJ, Jalilzadeh A, Didham RK, Soboleva T, Tompkins DM (2013) The Trojan female technique: a novel, effective and humane approach for pest population control. Proc R Soc B: Bio Sci 280:20132549. https://doi.org/10.1098/rspb.2013.2549

Gould F (2008) Broadening the application of evolutionarily based genetic pest management. Evolution 62:500-510 
Grunwald HA, Gantz VM, Poplawski G, Xu XRS, Bier E, Cooper KL (2019) Super-Mendelian inheritance mediated by CRISPR-Cas9 in the female mouse germline. Nature 566:105

Hammond A, Galizi R, Kyrou K, Simoni A, Siniscalchi C, Katsanos D, Gribble M, Baker D, Marois E, Russell S, Burt A (2016) A CRISPR-Cas9 gene drive system targeting female reproduction in the malaria mosquito vector Anopheles gambiae. Nature Biotechnol 34:78-83

Heil F, Hemmi H, Hochrein H, Ampenberger F, Kirschning C, Akira S, Lipford G, Wagner H, Bauer S (2004) Species-specific recognition of single-stranded RNA via toll-like receptor 7 and 8. Science 303:1526-1529

Herman RA, Zhuang M, Storer NP, Cnudde F, Delaney B (2019) Risk-only assessment of genetically engineered crops is risky. Trends Plant Sci 24:58-68. https://doi.org/10.1016/j. tplants.2018.10.001

Holmes ND, Griffiths R, Pott M, Alifano A, Will D, Wegmann AS, Russell JC (2015) Factors associated with rodent eradication failure. Bio Conserv 185:18-16

Hone J, Drake VA, Krebs CJ (2017) The effort-outcomes relationship in applied ecology: evaluation and implications. Bio Science 67:845-852

Hone J, Drake VA, Krebs CJ (2018) Evaluating wildlife management by using principles of applied ecology: case studies and implications. Wildlife Res 45:436-445

Hsu PD, Scott DA, Weinstein JA, Ran FA, Konermann S, Agarwala V, Li Y, Fine EJ, Wu X, Shalem O, Cradick TJ (2013) DNA targeting specificity of RNA-guided Cas9 nucleases. Nature Biotechnol 31:827

Hussain W, Mahmood T, Hussain J, Ali N, Shah T, Qayyum S, Khan I (2018) CRISPR/Cas system: a game changing genome editing technology, to treat human genetic diseases. Gene 685:70

Ito J, Ghosh A, Moreira LA, Wimmer EA, Jacobs-Lorena M (2002) Transgenic anopheline mosquitoes impaired in transmission of a malaria parasite. Nature 417:452-455. https://doi. org $/ 10.1038 / 417452 \mathrm{a}$

Jiang W, Bikard D, Cox D, Zhang F, Marraffini LA (2013) RNA-guided editing of bacterial genomes using CRISPR-Cas systems. Nature Biotechnol 31:233

Jones HP, Holmes ND, Butchart SH, Tershy BR, Kappes PJ, Corkery I, Aguirre-Muñoz A, Armstrong DP, Bonnaud E, Burbidge AA, Campbell K (2016) Invasive mammal eradication on islands results in substantial conservation gains. PNAS 113:4033-4038

Jorgensen RA, Atkinson RG, Forster RL, Lucas WJ (1998) An RNA-based information superhighway in plants. Science 279:1486-1487

KaramiNejadRanjbar M, Eckermann KN, Ahmed HM, Dippel S, Marshall JM, Wimmer EA (2018) Consequences of resistance evolution in a Cas9-based sex conversion-suppression gene drive for insect pest management. PNAS 115:6189-6194. https://doi.org/10.1073/pnas.1713825115

Khvorova A, Reynolds A, Jayasena SD (2003) Functional siRNAs and miRNAs exhibit strand bias. Cell 115:209-216

Kinnear JE (2018) Mammal conservation and invasive species control in Australia: harnessing a potential extinction machine. Aust Mammal 40:131-135

Kogan M (1998) Integrated Pest management: historical perspectives and contemporary developments. Annl Rev Entomol 43:243-270

Kyrou K, Hammond AM, Galizi R, Kranjc N, Burt A, Beaghton AK, Nolan T, Crisanti A (2018) A CRISPR-Cas9 gene drive targeting doublesex causes complete population suppression in caged Anopheles gambiae mosquitoes. Nature Biotechnol 36:1062-1066

Lamas-Toranzo I, Guerrero-Sánchez J, Miralles-Bover H, Alegre-Cid G, Pericuesta E, BermejoÁlvarez P (2017) CRISPR is knocking on barn door. Reprod Domest Anim 52:39-47. https:// doi.org/10.1111/rda.13047

Lander ES (2016) The heroes of CRISPR. Cell 164:18-28

Lares MR, Rossi JJ, Ouellet DL (2010) RNAi and small interfering RNAs in human disease therapeutic applications. Trends Biotechnol 28:570-579

Leftwich PT, Edgington MP, Harvey-Samuel T, Paladino LZC, Norman VC, Alphey L (2018) Recent advances in threshold-dependent gene drives for mosquitoes. Biochem Soc Trans 46:1203-1212 
Linnhoff S, Volovich E, Martin H, Smith M (2017) An examination of millennials' attitudes toward genetically modified organism (GMO) foods: is it Franken-food or super-food? IJARGE 13:371-390. https://doi.org/10.1504/IJARGE.2017.088403

Lipsitch M (2018) Why do exceptionally dangerous gain-of-function experiments in influenza? In: Influenza virus. Humana Press, New York, pp 589-608. https://doi. org/10.1007/978-1-4939-8678-1_29

Liu J, Carmel MA, Rivas FV, Marsden CG, Thomson JM, Song JJ, Hammond SM, JoshuaTor L, Hannon GJ (2004) Argonaute2 is the catalytic engine of mammalian RNAi. Science 305:1437-1441

MacKay JWB, Russell JC, Murphy EC (2007) Eradicating house mice from islands: successes, failures and the way forward. In: Witmer GW, Pitt WC, Fagerstone KA (eds) Managing vertebrate invasive species. Proceedings of an international symposium, Fort Collins, pp 294-304

Mali P, Yang L, Esvelt KM, Aach J, Guell M, DiCarlo JE, Norville JE, Church GM (2013) RNAguided human genome engineering via Cas9. Science 339:823-826

Mamta B, Rajam MV (2017) RNAi technology: a new platform for crop pest control. Physiol Mol Bio Plants 23:487-501

Morgan AP, Didion JP, Hughes JJ, Searle JB, Jolley WJ, Campbell KJ, Threadgill DW, Manuel de Villena FP (2018) Genetic characterization of invasive house mouse populations on small islands. BioRxiv. https://doi.org/10.1101/332064

Moro D, Byrne M, Kennedy M, Campbell S, Tizard M (2018) Identifying knowledge gaps for gene drive research to control invasive animal species: the next CRISPR step. Glob Ecol Conserv 13. https://doi.org/10.1016/j.gecco.2017.e00363

Napoli C, Lemieux C, Jorgensen R (1990) Introduction of a chimeric chalcone synthase gene into petunia results in reversible co-suppression of homologous genes in trans. Plant Cell 2:279-289

National Research Council (2015) Potential risks and benefits of gain-of-function research: summary of a workshop. National Academies Press. https://doi.org/10.17226/21666

NIH (2017) Intellectual property and genomics. National Institute of Health, Bethesda, MD. https:// www.genome.gov/19016590/

NIH (2019) Help Me Understand Genetic Testing. Lister Hill National Center for Biomedical Communications. National Institute of Health. Bethesda MD, March 19, 2019. https://ghr.nlm. nih.gov/primer/testing.pdf

Niu J, Taning CNT, Christiaens O, Smagghe G, Wang JJ (2018) Rethink RNAi in insect Pest control: challenges and perspectives. In: Smagghe G (ed) Advances in insect physiology, vol 2018. Academic Press, pp 1-17. https://doi.org/10.1016/bs.aiip.2018.07.003

Noble C, Adlam B, Church GM, Esvelt KM, Nowak MA (2018) Current CRISPR gene drive systems are likely to be highly invasive in wild populations. elife 7 . https://doi.org/10.7554/ eLife. 33423

OSTP (1986) Executive Office of the President, Office of Science and Technology Policy, Coordinated Framework for Regulation of Biotechnology. 122 p. 51 FR 23302. https://www. aphis.usda.gov/brs/fedregister/coordinated_framework.pdf

OSTP (2016) Executive Office of the President, National Strategy for Modernizing the Regulatory System for Biotechnology Products, p 14 https://obamawhitehouse.archives.gov/sites/default/ files/microsites/ostp/biotech_national_strategy_final.pdf

OSTP (2017) Executive Office of the President, Office of Science and Technology Policy, Modernizing the Regulatory System for Biotechnology Products: Final Version of the 2017 Update to the Coordinated Framework for Regulation of Biotechnology. 51 F.R. 23302-93. https://obamawhitehouse.archives.gov/sites/default/files/microsites/ostp/2017_coordinated_ framework_update.pdf

OSTP (2019) Executive order on modernizing the regulatory framework for agricultural biotechnology products. https://www.whitehouse.gov/presidentialactions/ executive-order-modernizing-regulatory-framework-agricultural-biotechnology-products/ 
Piaggio AJ, Segelbacher G, Seddon PJ, Alphey L, Bennett EL, Carlson RH, Friedman RM, Kanavy D, Phelan R, Redford KH, Rosales M (2017) Is it time for synthetic biodiversity conservation? Trends Ecol Evol 32:97-107

Prowse TA, Cassey P, Ross JV, Pfitzner C, Wittmann TA, Thomas P (2017) Dodging silver bullets: good CRISPR gene-drive design is critical for eradicating exotic vertebrates. Proc R Soc B Bio ScI 284:20170799

Prowse TA, Adikusuma F, Cassey P, Thomas P, Ross JV (2019) A Y-chromosome shredding gene drive for controlling pest vertebrate populations. eLife 8:e41873. https://doi.org/10.7554/ eLife. 41873

Reidinger RF Jr, Miller JE (2013) Wildlife damage management: prevention, problem solving, and conflict resolution. JHU Press, Baltimore

Restif O, Hayman DTS, Pulliam JRC, Plowright RK, George DB, Luis AD, Cunningham AA, Bowen RA, Fooks AR, O'Shea TJ, Wood JLN, Webb CT (2012) Model-guided fieldwork: practical guidelines for multidisciplinary research on wildlife ecological and epidemiological dynamics. Ecol Lett 15:1083-1094

Ruell EW, Gatewood DM, O'Hare JR, Eisemann JE (2016) A decision support tool for determining federal regulatory authority over products for vertebrate animals. Proc Vertebr Pest Conf 27:422-431

Sanvido O, Romeis J, Gathmann A, Gielkens M, Raybould A, Bigler F (2012) Evaluating environmental risks of genetically modified crops: ecological harm criteria for regulatory decisionmaking. Environ Sci Pol 15:82-91. https://doi.org/10.1016/j.envsci.2011.08.006

Schwarz DS, Hutvágner G, Du T, Xu Z, Aronin N, Zamore PD (2003) Asymmetry in the assembly of the RNAi enzyme complex. Cell 115:199-208

Schwarz DS, Ding H, Kennington L, Moore JT, Schelter J, Burchard J, Linsley PS, Aronin N, Xu Z, Zamore PD (2006) Designing siRNA that distinguish between genes that differ by a single nucleotide. PLoS Genet 2:e140. https://doi.org/10.1371/journal.pgen.0020140

SCOTUS (2013) Association for Molecular Pathology et al. v. Myriad Genetics, Inc. et al. Supreme Court of the United States. Decided June 13, 2013. https://www.supremecourt.gov/ opinions/12pdf/12-398_1b7d.pdf

Selle K, Barrangou R (2015a) CRISPR-based technologies and the future of food science. J Food Sci 80:R2367-R2372

Selle K, Barrangou R (2015b) Harnessing CRISPR-Cas systems for bacterial genome editing. Trends Microbio 23:225-232

Shaw WR, Catteruccia F (2019) Vector biology meets disease control: using basic research to fight vector-borne diseases. Nature Microbio 4:20-34. https://doi.org/10.1038/s41564-018-0214-7

Shinwari ZK, Tanveer F, Khalil AT (2017) Ethical issues regarding CRISPR-mediated genome editing. Cris Syst Emerg Technol Appl 26:103-110. https://doi.org/10.21775/cimb.026.103

Singh A, Trivedi P, Jain NK (2018a) Advances in siRNA delivery in cancer therapy. Artif Cells Nanomed Biotechnol 46:274-283

Singh T, Murthy AS, Yang HJ, Im J (2018b) Versatility of cell-penetrating peptides for intracellular delivery of siRNA. Drug Deliv 25:1996-2006

Sokolow SH, Nova N, Pepin KM, Peel AJ, Pulliam JRC, Manlove K, Cross PC, Becker DJ, Plowright RK, McCallum H, De Leo Giulio A (2019) Ecological interventions to prevent and manage zoonotic pathogen spillover. Phil Trans R Soc B. https://doi.org/10.1098/ rstb.2018.0342

Spatz DR, Zilliacus KM, Holmes ND, Butchart SH, Genovesi P, Ceballos G, Tershy BR, Croll DA (2017) Globally threatened vertebrates on islands with invasive species. Sci Adv 3(10). https:// doi.org/10.1126/sciadv. 1603080

Sudweeks J, Hollingsworth B, Blondel DV, Campbell KJ, Dhole S, Eisemann JD, Edwards O, Godwin J, Howald GR, Oh K, Piaggio AJ, ProwseTAA RJV, Saah JR, Shiels AB, Thomas P, Threadgill DW, Vella MR, Gould F, Lloyd A (2019) Locally fixed alleles: a method to localize gene drive to island populations. Sci Rep 9:15821. https://doi.org/10.1038/s41598-019-51994-0

Tang G (2005) siRNA and miRNA: an insight into RISCs. Trends Biochem Sci 30:106-114 
Tershy BR, Shen KW, Newton KM, Holmes ND, Croll DA (2015) The importance of islands for the protection of biological and linguistic diversity. Bioscience 65:592-597

Unckless RL, Clark AG, Messer PW (2017) Evolution of resistance against CRISPR/Cas9 gene drive. Genetics 205:827-841

Underwood W, Anthony R, Cartner S, Corey D, Grandin T, Greenacre CB, Gwaltney-Bran S, McCrackin MA, Meyer R, Miller D (2013) AVMA guidelines for the euthanasia of animals: 2013 edition. American Veterinary Medical Association, Schaumburg, IL. ISBN 978-1-882691-21-0

Van Eenennaam AL, Young AE (2014) Prevalence and impacts of genetically engineered feedstuffs on livestock populations. J Anim Sci 92:4255-4278. https://doi.org/10.2527/jas2014-8124

Wilkins KE, Prowse TA, Cassey P, Thomas PQ, Ross JV (2018) Pest demography critically determines the viability of synthetic gene drives for population control. Math Biosci 305:160-169. https://doi.org/10.1016/j.mbs.2018.09.005

Witmer G (2007) The ecology of vertebrate pests and integrated pest management (IPM). In: Kogan M, Jepson P (eds) Perspectives in ecological theory and integrated pest management. Cambridge University Press, Cambridge, UK, pp 393-341

Woinarski JC, Burbidge AA, Harrison PL (2015) Ongoing unraveling of a continental fauna: decline and extinction of Australian mammals since European settlement. PNAS 112:4531-4540

Wozniak CA (2018) Regulatory avenues at US EPA for products of novel breeding technologies. U.S. Environmental Protection Agency, Office of Pesticide Programs. http://cropbioengineering.iastate.edu/wp-content/uploads/2018/06/2-Day2_Wozniak.pdf

Wozniak CA, McClung G, Gagliardi J, Segal M, Matthews K (2012) Regulation of genetically engineered microorganisms under FIFRA, FFDCA and TSCA. In: Regulation of agricultural biotechnology: the United States and Canada. Springer, Dordrecht, pp 57-94. https://doi. org/10.1007/978-94-007-2156-2_4

Zhan X, Zhang F, Zhong Z, Chen R, Wang Y, Chang L, Bock R, Nie B, Zhang J (2019) Generation of virus-resistant potato plants by RNA genome targeting. Plant Biotechnol J 17:1814-1822

Zhang H, Kolb FA, Jaskiewicz L, Westhof E, Filipowicz W (2004) Single processing center models for human Dicer and bacterial RNase III. Cell 118:57-68

Zotti M, dos Santos EA, Cagliari D, Christiaens O, Taning CNT, Smagghe G (2018) RNA interference technology in crop protection against arthropod pests, pathogens and nematodes. Pest Managt Sci 74:1239-1250 